\title{
Differential profiling of prostate tumors versus benign prostatic tissues by using a 2DE-MALDI-TOF-based proteomic approach
}

\author{
Monika KMEŤOVÁ SIVOŇOVÁ ${ }^{1, *}$, Zuzana TATARKOVÁ ${ }^{1}$, Jana JUREČEKOVÁ ${ }^{1}$, Ján KLIMENT ${ }^{2}$, Márk HÍVEŠ ${ }^{1}$, Lucia LICHARDUSOVÁ \\ Peter KAPLÁN ${ }^{1}$ \\ ${ }^{1}$ Department of Medical Biochemistry, Comenius University in Bratislava, Jessenius Faculty of Medicine, Martin, Slovakia; ${ }^{2}$ Department of \\ Urology, Comenius University in Bratislava, Jessenius Faculty of Medicine and UHM, Martin, Slovakia; ${ }^{3}$ Biomedical Center Martin, Comenius \\ University in Bratislava, Jessenius Faculty of Medicine, Martin, Slovakia
}

${ }^{*}$ Correspondence: monika.kmetova.sivonova@uniba.sk

Received June 11, 2020 / Accepted August 26, 2020

\begin{abstract}
Oncoproteomic technologies offer a complementary approach to the understanding of cancer proteins' function and the translation of molecular knowledge into clinical practice. Our aim was to compare the proteomic profiles of prostate tumors versus benign prostatic hyperplasia $(\mathrm{BPH})$ tissues in order to identify modulated proteins as the potential biomarkers for prostate cancer. Proteins extracted from twenty prostate cancer tissue specimens and ten BPH tissues were analyzed by two-dimensional electrophoresis (2-DE) coupled with MALDI-TOF mass spectrometry. Western blot and quantitative realtime PCR (RT-PCR) were performed to confirm the different amounts of protein biomarkers revealed by 2DE combined with MALDI mass spectrometry. We found 42 spots whose expression in the prostate was altered more than 1.5 -fold compared with BPH tissue $(\mathrm{p}<0.05)$. These spots represented ten different proteins that were identified by a database search after mass spectrometry: they comprised proteins involved in the regulation of actin dynamics, the cytoskeleton, and cell motility (ACTG2, ACTA2, TPM1, DES, VIM, FLNA, and TAGLN), heat shock protein-27 (Hsp27), and proteins with other functions (TR and RANBP3). Subsequent western blot and RT-PCR assays for DES, VIM, TAGLN, and Hsp27 in prostate tumor tissues and BPH tissues confirmed the observations obtained by proteomic analysis. The cytoskeletal and cytoskeleton-associated proteins identified by this approach might be useful molecular targets for prostate cancer diagnostics and may contribute to novel therapies for prostate cancer.
\end{abstract}

Key words: proteomics, prostate cancer, mass spectrometry, protein expression, cytoskeleton

The incidence of prostate cancer has obvious geographic and ethnic differences. Prostate cancer is the second most frequent cancer diagnosis and the second cause of all cancer deaths among men reported in the USA and the European Union [1]. Moreover, it is the fourth most prevalent cancer and the sixth leading cause of cancer death worldwide [2]. The development and evolution of prostate cancer is a complex and heterogeneous process. Risk factors of prostate cancer involve age, genetic background, and environmental and lifestyle factors [3].

The concept of personalized medicine includes novel biomarkers that might facilitate the risk stratification of prostate cancer aggressiveness at the time of diagnosis and help to guide clinical treatment decisions and reduce overtreatment $[4,5]$. Proteomic and genomic technologies have accelerated the development of biomarkers. However, genomic analysis alone has some limitations. It cannot provide complete information concerning the cellular, subcellular, and intercellular functions in which proteins and not the genes govern functions, and for which no strict linear relationship exists between genes and the protein complement or "proteome" of a cell [6]. Therefore, cancer proteomics enables a more in-depth understanding of cancer as it enables the analysis of dynamic protein expression, posttranslational modifications, cellular and subcellular localizations, and protein-protein interactions $[7,8]$.

In recent years, new potential biomarkers for prostate cancer have been identified in a variety of biological materials (various cell cultures, prostate tumor tissue, and body fluids) by means of the proteomic approach (mass spectrometry, 2D electrophoresis, multiplex assays, and protein microarrays) [4]. This general method has identified a substantial number of proteins with known associations with prostate cancer, plus proteins not previously clearly related to prostate 
cancer, providing a starting point for further elucidation of their function in disease initiation and progression. These targets can be grouped into several large categories such as heat shock proteins, signaling proteins, and cytoskeletal proteins [9-11] and proteins involved in the cell cycle and apoptosis $[12,13]$, in multiple anabolic processes including fatty acid and protein synthesis, in ribosomal biogenesis and protein secretion, in the oxidative phosphorylation capacity in mitochondria $[14,15]$, and in cancer progression [16].

Despite the epidemiological link having been demonstrated between prostate cancer and benign prostatic hyperplasia (BPH), the pathogenesis of prostate cancer and $\mathrm{BPH}$ remains poorly understood. One serum biomarker that is widely used for prostate cancer diagnosis is the prostatespecific antigen (PSA). However, the PSA in the 'gray zone' from 4 to $10 \mathrm{ng} / \mathrm{ml}$ is limited in its ability to differentiate prostate cancer from $\mathrm{BPH}$; with a specificity of only $25-30 \%$ [17]. Intensive efforts are currently being directed towards a search for alternative prostate cancer biomarkers to allow the differentiation between these two most common diseases of the prostate gland. Therefore, the present study focuses on the differential profiling of the prostate cancer proteome by comparing proteins separated by two-dimensional gel electrophoresis coupled with MALDI-TOF mass spectrometry in samples from both prostate tumor tissues and $\mathrm{BPH}$ tissues. We considered that this method would provide important information relating to the malignant transformation of prostatic cells and might characterize potential biomarkers and molecular targets for early prostate cancer diagnostics.

\section{Patients and methods}

Tissue samples. The present study was approved by the Ethics Board of Jessenius Faculty of Medicine, Comenius University, and informed written consent was obtained from all individuals prior to the study. In total, twenty tissue samples from prostate cancer patients and ten tissue samples from patients with $\mathrm{BPH}$ were collected during routine surgery and stored in mRNA stabilizing solution (RNAlater; Applied Biosystems/Ambion, USA) at $-80^{\circ} \mathrm{C}$ until processed. The diagnosis of prostate cancer was made by transrectal ultrasound (TRUS)-guided biopsies in all patients. The indication for prostate biopsy was either a suspicious finding on digital rectal examination (DRE) or elevated serum levels of prostate specific antigen (PSA), or both. Prostate cancer patients who presented other cancers or other major pathologies were excluded. Prostate cancer patients and patients with $\mathrm{BPH}$ were tested for total serum PSA levels (Prostate specific antigen chemiluminescence immunoassay). Both groups were interviewed regarding age, previous and/or current prostate diseases, and incidence of cancer and chronic diseases. The studied population is described in Table 1.

Protein sample preparation for proteomics. All thirty tissue samples were processed under identical conditions.
The samples $(20 \mathrm{mg}$ ) were washed with $0.5 \mathrm{ml}$ of Dulbecco's phosphate-buffered saline (DPBS) solution and were then homogenized in ice-cold homogenization buffer $(30 \mathrm{mM}$ $\mathrm{KH}_{2} \mathrm{PO}_{4}, 5 \mathrm{mM}$ EDTA, $0.3 \mathrm{M}$ sucrose, and $0.3 \mathrm{mM}$ phenylmethyl-sulfonyl fluoride, $\mathrm{pH}$ 7.0) by using a SONOPLUS Ultrasonic Homogenizer HD3100 (BANDELIN, Germany). Proteins were extracted by vortexing for 1 hour at $4^{\circ} \mathrm{C}$. Samples were centrifuged at $12,000 \times \mathrm{g}$ for $15 \mathrm{~min}$ at $4{ }^{\circ} \mathrm{C}$. Subsequently, the insoluble fractions were discarded, and the soluble material was analyzed by $2 \mathrm{D}$ gel electrophoresis. Protein concentrations were determined by means of a protein Dc assay kit (BioRad Laboratories, Inc.) with bovine serum albumin (BSA) as a standard.

Two-dimensional PAGE and image analysis. Two-dimensional gel electrophoresis was carried out as previously described [18]. To eliminate contaminants, we added ice-cold acetone in a volume that was four times higher than the volume of the lysate. Each protein pellet was loaded into $11 \mathrm{~cm}$ nonlinear Ready Strip IPG strips pH3-10 (BioRad Laboratories, Inc.), which were equilibrated for 12-16 hours with rehydration buffer ( $8 \mathrm{M}$ urea, $2 \%$ CHAPS, 50 mM DTT, 0.2\% Bio-Lyte 3/10 ampholyte, and $0.001 \%$ bromophenol blue). Isoelectric focusing (IEF) was performed using the Protean IEF system (BioRad Laboratories, Inc.) in three steps, namely at $250 \mathrm{~V}$ for $20 \mathrm{~min}$, at $8000 \mathrm{~V}$ for $2.5 \mathrm{~h}$, and then at $8000 \mathrm{~V}$, until the total voltage reached 20,000 Vh. Prior to separation in the second dimension, strips were incubated in equilibration buffer I $(375 \mathrm{mM}$ Tris- $\mathrm{HCl}, \mathrm{pH} 8.8,6 \mathrm{M}$ urea, and 2\% SDS) for 15 minutes, first with $2 \%$ DTT and then with $0.03 \mathrm{~g} / \mathrm{ml}$ iodoacetamide. Separation in the second dimension was carried out in $12 \%$ homogeneous polyacrylamide gels by using the AE-6220 electrophoretic system (ATTO, Tokyo, Japan) for $20 \mathrm{~min}$ at $15 \mathrm{~mA} /$ gel and then at $30 \mathrm{~mA}$ until the bromophenol blue dye reached the bottom of the gel. The proteins were stained with Bio-Safe Coomassie G-250 stain (BioRad Laboratories, Inc.) and scanned on a GS-800 Calibrated Densitometer (BioRad Laboratories, Inc.).

Quantitative analysis of the images was performed by PDQuest 8 software (BioRad Laboratories, Inc.). All matched spots were then checked manually. Spots with a statistically significant differential abundance were selected based on two criteria: t-test $<0.05$ and fold change $>1.5$. Selected protein spots with significant differences were subsequently identified by mass spectrometry.

In-gel digestion of proteins and protein identification by mass spectrometry. Protein spots were cut out manually and were digested as described previously [18]. Briefly, the gel pieces were destained twice with $50 \%$ acetonitrile $\left(\mathrm{CH}_{3} \mathrm{CN}\right)$ in $25 \mathrm{mM}$ ammonium bicarbonate at room temperature overnight for the first destaining step and with $100 \%$ $\mathrm{CH}_{3} \mathrm{CN}$ for an additional $15 \mathrm{~min}$ for the second destaining step. Subsequently, the dried gel spots were reduced, alkylated, and then rinsed with $25 \mathrm{mM}$ ammonium bicarbonate followed by $100 \% \mathrm{CH}_{3} \mathrm{CN}$. After removal of the liquid, the 
gel pieces were allowed to dry by volatilization in opened test tubes. The proteins were then digested with $3 \mathrm{ml}$ of $20 \mathrm{mg} / \mathrm{ml}$ trypsin (Promega, Madison, WI, USA) for $30 \mathrm{~min}$ on ice. After digestion, the tryptic peptides were incubated with 25 $\mathrm{mM}$ ammonium bicarbonate at $37^{\circ} \mathrm{C}$ overnight in a shaking incubator. Finally, they were dissolved in $1 \mathrm{ml}$ of $10 \%$ trifluoroacetic acid.

The protein digest was concentrated in a vacuum centrifuge, and $0.75 \mathrm{ml}$ was applied onto an AnchorChip ${ }^{\mathrm{TM}}$ target (BrukerDaltonics, Bremen, Germany) together with $1 \mathrm{ml}$ of matrix (a-cyano-4 hydroxy cinnamic acid) and left to dry at room temperature. For MS analysis, samples were analyzed by MALDI-TOF mass spectrometry on an UltraflexIII mass spectrometer (Bruker Daltonics, Bremen, Germany). Mass spectra were acquired in the positive ion reflectron mode, with an accelerating voltage of $20 \mathrm{kV}$ and pulsed extraction, across the $\mathrm{m} / \mathrm{z}$ range $700-3000$. The instrument was calibrated with a peptide calibration standard (Bruker). External calibration was performed using a calibration standard mixture containing $[\mathrm{M}+\mathrm{H}]^{+}$ions of bradykinin, angiotensin I, angiotensin II, substance $\mathrm{P}$, bombesin, adrenocorticotropin fragments $1-17$ and $18-39$, and somatostatin. A list of peaks was created using Flex Analysis 3.4 (Bruker Daltonics, Bremen, Germany). Proteins were identified by peptide mass fingerprinting (PMF) and MS/MS fragmentation. MS/MS fragmentation spectra were obtained by selecting the two strongest peaks of each peptide mass map. The MS and MSMS spectra were combined by BioTools 3.2 software (Bruker), and a search was undertaken for appropriate candidates in the annotated NCBI non-redundant protein database and Swiss-Prot 2017_03 databases by using Mascot software (Matrix Science Ltd., London, UK). The following parameters were used in the database search: trypsin, taxonomy: human, one missed cleavage site allowed, fixed modification: carbamidomethylating, variable modification: methionine oxidation, mass tolerance for PMF 50 $\mathrm{ppm}, \mathrm{MS} / \mathrm{MS}$ tolerance 0.5 . Positive identification was based on a Mascot score greater than 65, above the significance level $(p<0.05)$. Presented scores are combinations of MS and MS/MS measurements.

Protein characterization and protein-protein networks. Biological functions of differentially expressed proteins were explored using the UniProt database. Analysis of functional protein-protein interactions associated with these proteins was predicted using STRING software (http://www.stringdb.org/) [19].

Western blot analysis. Total proteins $(30 \mu \mathrm{g})$ were loaded onto $12 \%$ SDS-PAGE gels, and after electrophoresis, the separated proteins were transferred onto nitrocellulose membranes by using a semi-dry transfer protocol. Non-specific binding was blocked with $5 \%$ non-fat dry milk in TBS-T (Tris base saline, $0.05 \%$ Tween 20) for at least $2 \mathrm{~h}$. They were then incubated with the following primary antibodies at $4{ }^{\circ} \mathrm{C}$ overnight: mouse monoclonal antidesmin (1:200, ab8470), anti-vimentin (1:1000, ab8978), or
anti-Hsp27 (1:500, ab2790) antibodies or rabbit monoclonal anti-TAGLN (1:500, ab170902) or anti- $\beta$-actin (1:500, sc-1616) antibodies. On the following day, membranes incubated with primary antibodies were washed with TBS-T solution (50 mM Tris-Cl, pH 7.5, $150 \mathrm{mM} \mathrm{NaCl}$, and $0.05 \%$ Tween 20) and then incubated with secondary antibodies conjugated with horseradish peroxidase (1:5000, Santa Cruz) for 1 hour. After extensive washes with TBS-T solution (3 times $15 \mathrm{~min}$ ), membranes were incubated in SuperSignal West Pico Chemiluminescent Substrate (Thermo Scientific, Rockford, IL, USA) solution for 3 min in dark. After exposure of the membranes to Chemidoc XRS (BioRad Laboratories, Inc.), the intensities of the relevant bands were quantified using Quantity One software (BioRad Laboratories, Inc.). The intensities of the bands of interest were normalized against corresponding intensities of bands of $\beta$-actin.

RNA isolation and quantitative RT-PCR. Total RNA was isolated from all prostate tumor tissue and $\mathrm{BPH}$ tissues by an AllPrep DNA/RNA/miRNA Universal Kit (Qiagen GmbH, Hilden, Germany). The amount of extracted RNA was quantified with a Nanophotometer (Implen GmbH, München, Germany). First-strand cDNAs were synthesized from total RNA $(1 \mu \mathrm{g})$ by using an RT ${ }^{2}$ First Strand Kit (Qiagen $\mathrm{GmbH}$, Hilden, Germany) according to the manufacturer's protocol. Real-time PCR analysis of selected genes expression was performed using the Custom $\mathrm{RT}^{2}$ Profiler PCR array (Qiagen $\mathrm{GmbH}$, Hilden, Germany). Two endogenous control genes, namely glyceraldehyde-3-phosphate dehydrogenase (GAPDH) and $\beta$-actin (ACTB), present on the PCR array were used for normalization. The data were analyzed by the $2^{-\Delta \Delta \mathrm{Ct}}$ method; the value of $2^{-\Delta \Delta \mathrm{Ct}}$ indicated the fold change in relative gene expression normalized to the average $\mathrm{C}_{\mathrm{T}}$ of two endogenous controls on a plate-by-plate basis [20].

Statistical analysis. Data are expressed as mean \pm standard error of the mean (SEM). Differences between groups were compared by the two-tailed Student $t$-test. A value of $p<0.05$ was considered to be statistically significant.

\section{Results}

The clinicopathologic characteristics of prostate cancer patients and patients with BPH are presented in Table 1. No significant difference was noted in the ages between prostate cancer patients and patients with BPH. The total serum PSA levels measured at the time of diagnosis were significantly higher among prostate cancer patients than in patients with BPH $(38.1 \pm 11.2 \mathrm{ng} / \mathrm{ml}$, vs. $1.6 \pm 0.3 \mathrm{ng} / \mathrm{ml} ; \mathrm{p}<0.05)$. Out of 20 patients, $10(50 \%)$ had a higher Gleason score $(>7)$, and 10 $(50 \%)$ had a lower Gleason score $(\leq 7)$. Approximately $65 \%$ of the cases had a pathological tumor stage of T3, and $30 \%$ of the cases were classified as T4.

Comparison of proteome difference between prostate tumor tissues and BPH tissues. We used MALDI-TOF mass spectrometry to identify the proteome of prostate tumor tissues. In total, $302 \mathrm{D}$ gels were generated, with each gel 
containing $\sim 280$ protein spots (Supplementary Figure S1). Representative gel images of proteins from prostate tumor tissue and $\mathrm{BPH}$ tissue are shown in Figure 1. The circles indicate spots of differently abundant proteins. A total of 42 spots from the prostate tissue of the cancer patients showed

Table 1. Characteristics of the study groups.

\begin{tabular}{lcc}
\hline & BPH & Prostate cancer \\
\hline Number $(\mathrm{n})$ & 10 & 20 \\
Age (years, mean \pm SEM) & $72 \pm 1.3$ & $72.2 \pm 1.9$ \\
PSA (ng/ml) & $1.6 \pm 0.3$ & $\mathbf{3 8 . 1 \pm 1 1 . 2}$ \\
Gleason score & NA & $7.7 \pm 0.3$ \\
Pathological stage no (\%) & & \\
pT1 & NA & $1(5 \%)$ \\
pT3 & NA & $13(65 \%)$ \\
pT4 & NA & $6(30 \%)$ \\
\hline
\end{tabular}

NA-not applicable; bold characters represent $\mathrm{p}<0.05$
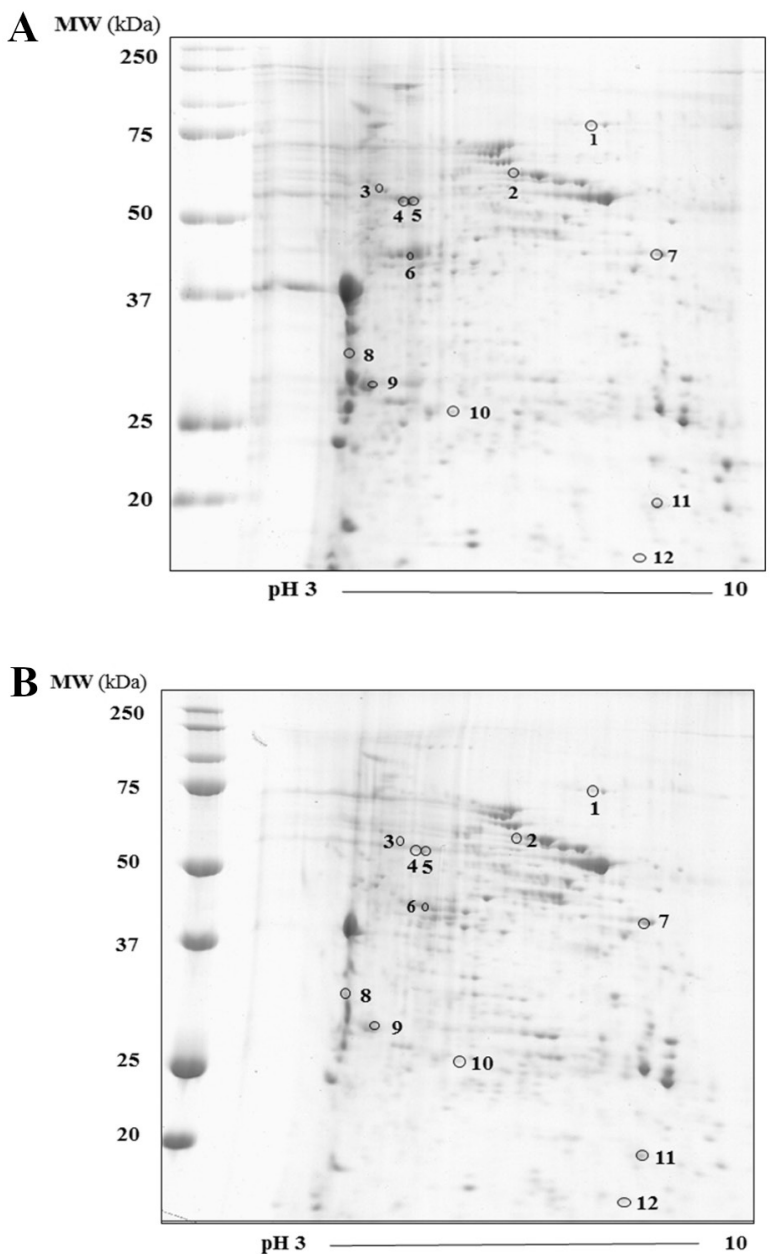

Figure 1. Representative 2D-PAGE gels of specimens from patients with A) $\mathrm{BPH}$ or B) prostate cancer. Spots showing significant changes in their expression are labeled by numbers. Spot numbers correspond to those listed in Table 2. statistically significant $(\mathrm{p}<0.05) \quad 1.5$-fold variation or more in abundance. Only those protein spots that were uniquely altered between prostate cancer versus $\mathrm{BPH}$ patients were excised from the gels. However, the majority of the protein spots with a differential abundance were either part of the most abundant protein in the blood, later identified as albumin, or were low-quality spots. We identified the following proteins: actin, gamma-enteric smooth muscle (ACTG2); actin, aortic smooth muscle (ACTA2); tropomyosin alpha-1 chain (TPM1); desmin (DES); vimentin (VIM); filamin A (FLNA); transgelin (TAGLN); heat shock protein-27 (Hsp27); ran-binding protein 3 (RANBP3); and serotransferrin (TR). DES, TAGLN, and TR were detected in 5,3 , and 2 different spots, respectively, indicating the modification or degradation of the native protein. Some spots displayed different isoelectric points (pI), probably because of post-translational modifications. Moreover, the different isoforms of a protein might have been generated during alternative splicing at the mRNA level, allowing a single gene to express multiple protein variants possibly with different functions [21]. All altered proteins were significantly downregulated in the prostate cancer tissues in comparison with $\mathrm{BPH}$ tissues $(\mathrm{p}<0.05)$. The individual optical densities from the measurements of 12 identified spots in BPH tissues and prostate cancer tissues are presented in Supplementary Table S1. The identified proteins and their biochemical properties and MS characteristics are shown in Table 2.

To determine the protein-protein interactions of differentially expressed proteins, we utilized the STRING database (Figure 2). The identified pathways with the highest score involved muscle contraction, tissue morphogenesis, tissue development, and cytoskeleton organization.

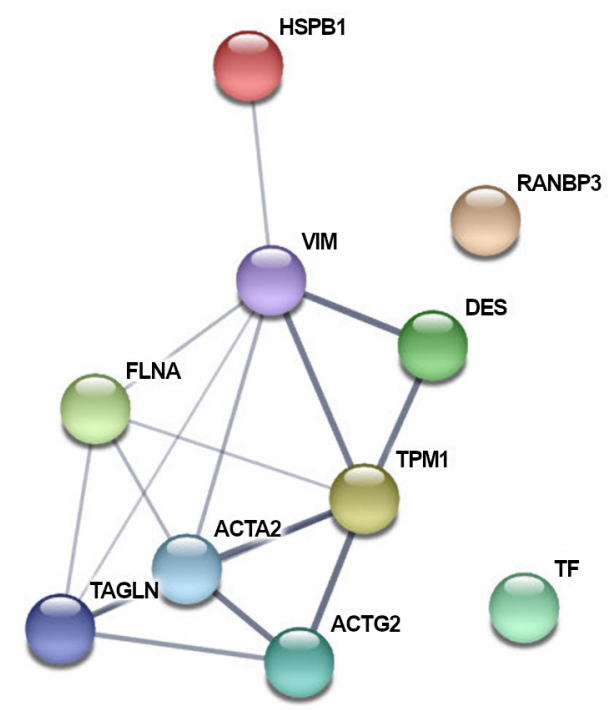

Figure 2. Protein-protein interactions generated by the STRING software analysis of differentially expressed proteins. 
Table 2. Identification of differentially expressed proteins in prostate tumor tissues and BPH tissues.

\begin{tabular}{|c|c|c|c|c|c|c|c|c|c|c|}
\hline $\begin{array}{l}\text { Spot } \\
\text { no. }\end{array}$ & Protein ID & $\begin{array}{c}\text { UniProt } \\
\text { accession no. }\end{array}$ & Gene ID & $\underset{(\mathrm{kDa})}{\mathrm{M}_{\mathrm{w}}}$ & pI & $\begin{array}{c}\text { Fold change } \\
\text { Prostate cancer/ } \\
\text { BPH }\end{array}$ & $\begin{array}{l}\text { Matched } \\
\text { peptides }\end{array}$ & $\begin{array}{l}\text { MS } \\
\text { score }\end{array}$ & $\begin{array}{l}\text { MSMS } \\
\text { score }\end{array}$ & $\begin{array}{c}\text { Sequence } \\
\text { coverage } \\
(\%)\end{array}$ \\
\hline 1 & Serotransferrin & P02787 & TR & 79294 & 6.81 & 0.56 & 23 & 257 & 294 & 31 \\
\hline 2 & Ran-binding protein 3 & Q9H6Z4 & RANBP3 & 60515 & 4.70 & 0.36 & 3 & 32 & 32 & 10 \\
\hline 3 & Vimentin & P08670 & VIM & 53676 & 5.06 & 0.25 & 10 & 115 & 192 & 33 \\
\hline 4 & Desmin & P17661 & DES & 53560 & 5.21 & 0.24 & 3 & 30 & 45 & 10 \\
\hline 5 & Desmin & P17661 & DES & 53560 & 5.21 & 0.18 & 8 & 100 & 108 & 27 \\
\hline 6 & Actin, gamma-enteric smooth muscle & P63267 & ACTG2 & 42249 & 5.31 & 0.22 & 7 & 84 & 200 & 25 \\
\hline 7 & Filamin-A & P21333 & FLNA & 283301 & 5.70 & 0.30 & 10 & 56 & 134 & 5 \\
\hline 8 & Tropomyosin alpha-1 chain & P09493 & TPM1 & 32746 & 4.69 & 0.42 & 8 & 64 & 91 & 20 \\
\hline 9 & Actin, aortic smooth muscle & P62736 & ACTA2 & 42381 & 5.32 & 0.43 & 6 & 48 & 169 & 18 \\
\hline 10 & Heat shock protein 27 & P04792 & HSPB1 & 22826 & 5.98 & 0.50 & 3 & 32 & 103 & 16 \\
\hline 11 & Transgelin & Q01995 & TAGLN & 22653 & 8.87 & 0.53 & 5 & 63 & 112 & 34 \\
\hline 12 & Transgelin & Q01995 & TAGLN & 22653 & 8.87 & 0.41 & 7 & 73 & 110 & 34 \\
\hline
\end{tabular}

Proteins were identified by 2-DE followed by combined MS and MS/MS analysis. The mass and pI values were obtained from the MASCOT database. Spots 4,5 and spots 11,12 were identified as the same proteins.
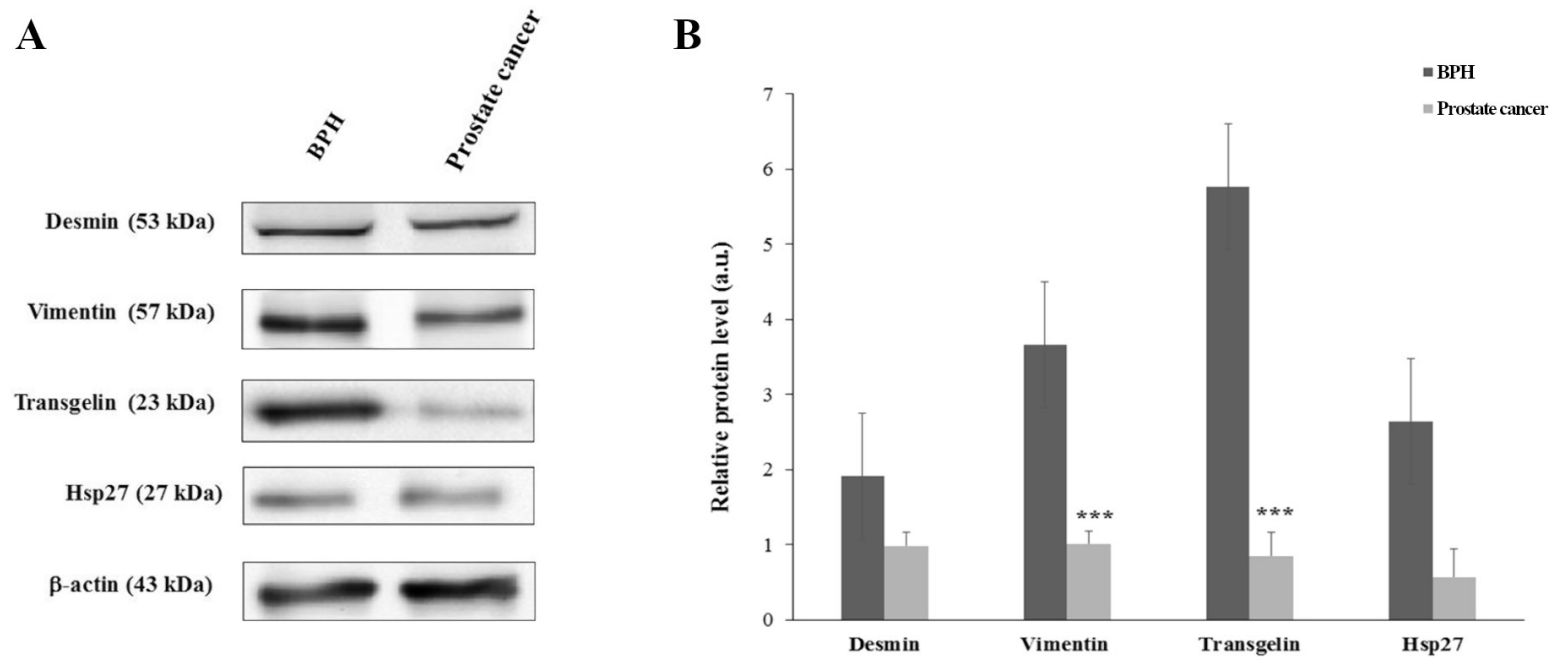

Figure 3. Western blot analysis of desmin, vimentin, transgelin, and Hsp27 and of $\beta$-actin as a house-keeping protein in prostate cancer tissue and BPH tissue samples. A) Western blot analysis. B) Relative protein expression levels were calculated densitometrically in reference to the $\beta$-actin expression level. Values are given as means \pm SEM. ${ }^{* *} \mathrm{p}<0.001$; significantly different when compared with BPH tissues.

Expression of selected proteins by western blot and quantitative RT-PCR. Based on the results from MALDITOF mass spectrometry, network analysis, and the literature search, four candidates (DES, VIM, TAGLN, and Hsp27) were selected for examination of their levels by western blot. Additionally, VIM and Hsp27 were selected, because of the observed diversity between our study and previously published studies, with the aim of evaluating the significance of VIM and Hsp27 expression in regard to its potential relevance as a diagnostic, prognostic, or predictive marker in prostate cancer as a complicated multistep process.

As shown in Figure 3, western blot confirmed our MALDI-TOF mass spectrometry findings showing that the protein levels of VIM and TAGLN were significantly lower in prostate tumor tissues relative to BPH tissues $(\mathrm{p}<0.001)$. Levels of DES and Hsp27 were also lower but, because of larger variations among the samples, the changes were not significant.

To test whether any changes occurred at the transcriptional level of these four selected proteins, we compared the mRNA levels by performing RT-PCR on all tissue samples obtained from prostate cancer patients and patients with $\mathrm{BPH}$. The result demonstrated that the gene expression levels of those proteins exhibited the same tendency of changes as the 2-DE-MS and western blot results. As shown in Figure 4, DES, VIM, TAGLN, and Hsp27 mRNA expression in prostate tumor tissues was $1.8,1.5,1.8$, and 2.1 times lower than in $\mathrm{BPH}$ tissues, respectively $(\mathrm{p}<0.05$ and $\mathrm{p}<0.01)$. 


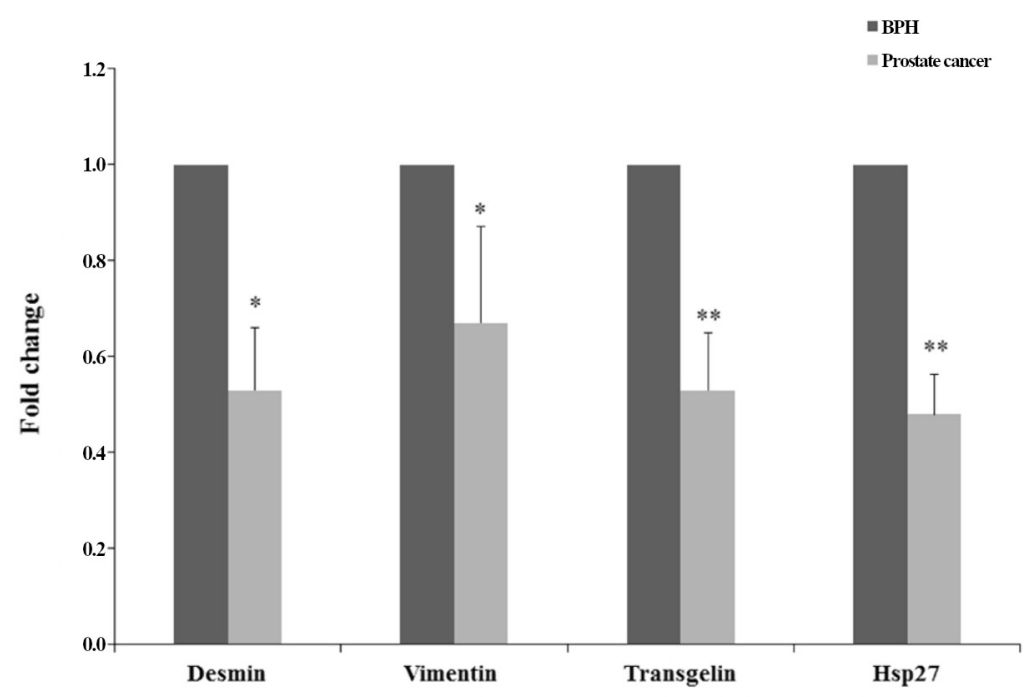

Figure 4. Fold change of gene expression in the prostate cancer tissues. Values are given as means $\pm \mathrm{SEM}$. ${ }^{\star} \mathrm{p}<0.05$; ${ }^{\star *} \mathrm{p}<0.01$; significantly different when compared with BPH tissues.

\section{Discussion}

Prostate cancer is a heterogeneous disease with variations within a single tumor. Therefore, novel prognostic or predictive biomarkers are urgently needed that, when combined with clinical factors, can help establish effective risk predictive models to improve the earlier diagnosis of prostate cancer. The integration of proteomics findings with genomics and transcriptomics data can offer unique information for biomarker research and might even be important in the decision-making process with regard to treatment and the development of new effective therapies. Previous proteomic studies of prostate cancer have identified a large number of differentially expressed proteins $[14,22,23]$ in tumor tissue compared with tumor-free prostate tissue or benign hyperplasia. Some of these proteins have been identified as new biomarkers that improve the early non-invasive detection and stratification of prostate cancer patients [24-26]. In the present study, by comparing the proteome of prostate tumors versus benign prostatic tissues by using a 2DE-based proteomic approach, we have identified ten downregulated proteins in prostate cancer tissues, including mainly cytoskeletal and cytoskeleton-associated proteins such as the family of actins, tropomyosin alpha-1 chain, desmin, vimentin, filamin A, and transgelin. Moreover, Hsp27, ran-binding protein 3, and serotransferrin have been found to be downregulated. All of the proteins, except for ran-binding protein 3, have been previously deemed to be involved in prostate cancer progression $[9,10,23]$. The major strength of our study is that we have identified proteins that are related to the cytoskeleton, that exhibit altered expression, that participate in fundamental cellular functions, that play an important role in tumor invasiveness, and that might be promising biomarkers for the differentiation between prostate cancer and $\mathrm{BPH}$. The observed divergence of the levels for VIM and Hsp27 between our study and data from the current literature suggests that their amount is highly dependent on the unique molecular context of each tumor type, on genetic and epigenetic changes, and on protein expression profiles.

The prostatic gland is composed of two distinctive compartments: epithelial and stromal. During the process of prostatic carcinogenesis, progressive changes occur that include the development of a reactive stromal phenotype and the possible promotion, by stromal cells, of epithelial proliferation and the loss of differentiated function [27]. Reactive stroma in prostate cancer tissue is characterized by an increase in myofibroblasts and fibroblasts, with a significant decrease or loss of smooth muscle cells as prostate cancer progresses [28]. Stromal cells secrete growth factors, produce an extracellular matrix, and express androgen receptor, estrogen receptor, adrenergic receptor, and 5-a reductase. Fibroblasts express vimentin and laminin, whereas smooth muscle cells express desmin, a-actin, calponin, caldesmon, myosin, smoothelin, and dystrophin [29]. Mesenchymal markers such as procollagen 1, tenascin, fibroblast activation protein, vimentin, and smooth muscle alpha-actin are all expressed in myofibroblasts relatively early in the genesis of reactive stroma in prostate cancer [30].

Cytoskeletal proteins, which consist of various sub-families of proteins including microtubules, actin, and intermediate filaments, are essential for survival and cellular processes in normal cells. However, in cancer cells, these proteins are often dysregulated. This is in agreement with well-known features of cancer: the promotion of tumor development and progression, whereby the functions of cytoskeletal proteins are co-opted to facilitate increased migrative and invasive capabilities, proliferation, and resistance to cellular and environmental stresses [31, 32]. Actin cytoskeleton 
remodeling plays a pivotal role in cancer, since it is essential for cell proliferation and migration, and requires the fine orchestration of actin microfilaments, intermediate filaments, and microtubules [33]. Actin is functionally associated with tropomyosin and troponins. Tropomyosin binds to actin filaments and has been implicated in the stabilization of the actin cytoskeleton. Interestingly, an opposing expression regulation for the different tropomyosin isoforms has often been found in tumors, implying that these isoforms have diverse functions in cell transformation [34].

Desmin and vimentin are type III intermediate filaments. DES is not only expressed by smooth muscle cells but is also found in fibrotic tissue in wound healing and in tumor 'desmoplastic' stroma [35] and is a highly sensitive marker for endothelial cell differentiation and tumor invasiveness in several types of cancers [36]. Reduced expression of DES has been detected in human prostate cancer cell lines (PCLNcap, DU145, PC-3, and PC-3M) [37]. Previous proteomic studies concerning the differential expression of this protein in prostate tumor tissues have given conflicting results, from an increased amount of desmin [13] to a reduced amount [10, 38,39 ], in agreement with our study. Ayala et al. [40] have shown that reduced desmin and smooth muscle-actin are hallmarks of a cancer-associated reactive stroma relative to a normal fibromuscular stroma and are a significant predictor of prostate cancer recurrence.

Previous investigations have demonstrated the involvement of vimentin in the epithelial-mesenchymal transition (EMT), which is an essential process that occurs when the primary tumor transforms into a malignant one [41]. VIM expression has been noted in various epithelial cancers such as ductal carcinoma of the breast, prostate cancer, and gastrointestinal tumors [42]. An increased amount of VIM has been shown to be usually associated with a higher grade and aggressiveness of the tumor in prostate cancer [43, 44]. A higher amount of VIM has been detected in the central zone of the prostate relative to the peripheral zone [45]. Significant expression of VIM has also been detected in 1E8-H cells (high metastatic potential) compared with 2B4-L cells (low metastatic potential) [46]. In our study, we have observed a significant decrease in the amount of VIM between prostate tumor tissues and BPH tissues by 2-DE, western blot, and gene expression analyses. Similar to our findings, the downregulation of VIM has been described in prostatectomy samples from prostate cancer patients in comparison with corresponding tumor-free prostate cancer tissue samples [38].

How can we explain this discrepancy between our study and the widely accepted theory of vimentin overexpression that correlates with a more malignant phenotype in cancer? We assume that several factors can decrease the expression of vimentin by its regulation at the transcriptional, translational, and post-translational levels in tumors. First, we hypothesize that the reason for decreased vimentin expression may be the fluctuating expression of several microRNAs (miRs) that bind to the 3 ' untranslated region of vimentin mRNA in prostate cancer cells. The overexpression of miR-519 [47], miR-1246 [48], miR-19a-3p [49], miR-129-5p [50], miR-200b [51], and others miRs causes a downregulation of vimentin in various prostate cancer cell lines. Furthermore, vimentin expression might be regulated by hypoxia-inducible factor 1 (HIF-1), which plays important roles in tumor progression [52]. Moreover, the posttranslational modifications of vimentin, mainly phosphorylation on at least 23 identified phosphorylation sites on its $\mathrm{N}$-terminus and C-terminus, has been shown to enhance tumor and metastasis growth in vivo [53]. The expression of vimentin might be dynamically dependent on the in vivo cellular environment, and the collaboration of vimentin with other factors in the stroma might be necessary to create a microenvironment favorable for tumor progression.

Filamin A is a non-muscle actin filament cross-linking protein or gelation factor. This protein mediates cell signaling, cell motility, phosphorylation, proteolysis, ion channel regulation, transcription regulation, receptor activation, and muscle development [54]. It is an important regulator of the EMT and is considered a potential marker of metastasis and poor prognosis [55]. Bedolla et al. [56] have shown that metastatic prostate cancer tissues express high levels of cytoplasmic FLNA and low levels of nuclear FLNA compared with localized cancers, and its presence in the cytoplasm might be used as a predictive marker of future metastasis. Furthermore, a reduced FLNA amount has been demonstrated to correlate with the $\mathrm{T}$ stage, lymph node metastasis, clinical stage, and Gleason score, but not with age or PSA concentration [57]. Our study has revealed the lower abundance of FLNA in prostate tumor tissues in comparison with $\mathrm{BPH}$ tissues probably because of differences in the subcellular localization of FLNA. As has been hypothesized, the function of FLNA in the cell depends on the binding partners available for its interaction, and FLNA remains as a scaffolding protein that only acts, whether in the cytoplasm or the nucleus, to promote the interaction of these proteins either to promote or prevent cancer [58].

Heat shock proteins (HSPs) are molecular chaperones that are involved in protein-protein interactions such as folding/ unfolding, the establishment of proper protein conformation, and the prevention of unwanted protein aggregation. Their expression is induced by a range of environmental and pathophysiological stimuli, such as hyperthermia, exposure to heavy metal ions, hypoxia, hyperoxia, or exposure to cytotoxic agents [59]. Hsp27 is a member of this family of proteins. In addition to its chaperone function, Hsp27 has been shown to have an anti-apoptotic role by the inhibition of caspase-dependent apoptosis, preventing a wide variety of apoptotic agents from causing cell death [60]. Hsp27 has further been shown to interact with actin and intermediate filaments, to contribute to the process of cell differentiation, and to be involved in the activation of the proteasome. Higher levels of Hsp27 are commonly detected in many cancers, including those of the prostate, and is associated 
with metastasis and poor clinical outcome for prostate cancer [58-63]. Our proteomic, western blot, and gene expression analyses have demonstrated a reduced amount of Hsp27 in prostate tumor tissues. We hypothesize that Hsp27 protein abundance varies, during the different stages of prostate cancer or as a result of its diverse nature, based on several mechanisms. The expression of HSPs is regulated by the heat shock transcription factors (HSFs) that also orchestrate the survival of cells in response to various forms of cellular stress [64]. We assume that various influences, including environmental, non-stress, and pathological conditions, can trigger HSP expression via the HSF1 pathway. Another possible mechanism leading to reduced Hsp27 expression might be mediated by the pro-inflammatory cytokines (tumor necrosis factor- $\alpha$, interleukin- $1 \beta$, interferon- $\gamma$ ), with no effect on HSF-1, as has been shown in human retinal endothelial cells [65]. Moreover, various naturally processed Hsp27 isoforms have been shown to be up- or downregulated in prostate cancer tissues and may have functions in the malignant transformation of tissues [23]. Finally, Hsp27 is constitutively expressed in the cytoplasm of many normal and malignant cell types in the absence of stress, with wide variations with regard to the basal level of expression among various tissues [66].

Our study has revealed a significant downregulation of TAGLN, which is an actin-binding protein involved in the formation of stress fibers in both muscle and non-muscle cells [67]. Moreover, it is actively involved in cell differentiation, tissue invasion, matrix remodeling, and tumor suppression [68]. TAGLN has also be reported to interact with p53, to induce apoptosis, and to inhibit the androgen receptor pathway in prostate cancer cells [69]. Both the upregulation and downregulation of TAGLN have been linked to prostate cancer development and progression $[23,70]$.

Our proteomic analysis has detected a decreased amount of ran-binding protein 3 and an iron-binding transport protein in blood serum, serotransferrin. To the best of our knowledge, RANBP3 has not yet been identified in prostate tumor tissue. RANBP3 is primarily a nuclear Ran-binding protein that functions as an accessory factor in the Ran GTPase system. RANBP3 is also a cofactor for CRM1-mediated nuclear export and for the CRM1-independent nuclear export of $\beta$-catenin, Smad2, and Smad3 [71].

In conclusion, since prostate cancer is a heterogeneous disease, comprehensive and in-depth prostate cancer proteomic profiling is needed for the development of optimal biomarkers for the screening and early detection of tumors, for the characterization of the mechanism of disease progression, and for precise target treatment. We have identified ten proteins with significantly altered abundance in human prostate tumor tissues versus BPH tissues. Most of these proteins are involved in cell motility and cytoskeleton formation and thus might potentially be markers for diagnostics or targets for therapeutic intervention. To examine their potential, further research is warranted to define the way in which the cytoskeleton remodeling of these proteins specifically contributes to prostate cancer aggressiveness.

Supplementary information is available in the online version of the paper.

Acknowledgments: This work was supported by the Agency of Ministry of Education, Science, Research and Sport of the Slovak Republic under grants no. 1/0172/18 and no. 1/0271/19. This publication is the result of the project implementation: "Center of excellence for research in personalized therapy “, ITMS: 26220120053.

\section{References}

[1] SIEGEL RL, MILLER KD, JEMAL A. Cancer statistics, 2019. CA Cancer J Clin 2019; 69: 7-34. https://doi.org/10.3322/ caac. 21551

[2] BRAY F, FERLAY J, SOERJOMATARAM I, SIEGEL RL, TORRE LA et al. Global cancer statistics 2018: GLOBOCAN estimates of incidence and mortality worldwide for 36 cancers in 185 countries. CA Cancer J Clin 2018; 68: 394-424. https://doi.org/10.3322/caac.21492

[3] ZIARAN S, VARCHULOVA NOVAKOVA Z, BOHMER D, DANISOVIC L. Biomarkers for determination prostate cancer: implication for diagnosis and prognosis. Neoplasma 2015; 62: 683-691. https://doi.org/10.4149/neo_2015_082

[4] TANASE CP, CODRICI E, POPESCU ID, MIHAI S, ENCIU $\mathrm{AM}$ et al. Prostate cancer proteomics: Current trends and future perspectives for biomarker discovery. Oncotarget 2017; 8: 18497-18512. https://doi.org/10.18632/oncotarget.14501

[5] GAUDREAU PO, STAGG J, SOULIÈRES D, SAAD F. The Present and Future of Biomarkers in Prostate Cancer: Proteomics, Genomics, and Immunology Advancements. Biomark Cancer 2016; 8: 15-33. https://doi.org/10.4137/BIC. S31802

[6] PATTERSON SD, AEBERSOLD RH. Proteomics: the first decade and beyond. Nat Genet 2003; 33: 311-323. https:// doi.org/10.1038/ng1106

[7] KOWALCZYK T, CIBOROWSKI M, KISLUK J, KRETOWSKI A, BARBAS C. Mass spectrometry-based proteomics and metabolomics in personalized oncology. Biochim Biophys Acta Mol Basis Dis 2020; 1866: 165690. https://doi. org/10.1016/j.bbadis.2020.165690

[8] TONRY CL, LEACY E, RASO C, FINN SP, ARMSTRONG J et al. The Role of Proteomics in Biomarker Development for Improved Patient Diagnosis and Clinical Decision Making in Prostate Cancer. Diagnostics (Basel) 2016; 6: 27. https:// doi.org/10.3390/diagnostics6030027

[9] CHEN L, CAI J, HUANG Y, TAN X, GUO Q, et al. Identification of cofilin-1 as a novel mediator for the metastatic potentials and chemoresistance of the prostate cancer cells. Eur J Pharmacol 2020; 173100. https://doi.org/10.1016/j. ejphar.2020.173100

[10] ALAIYA AA, AL-MOHANNA M, ASLAM M, SHINWARI Z, AL-MANSOURI L et al. Proteomics-based signature for human benign prostate hyperplasia and prostate adenocarcinoma. Int J Oncol 2011; 38: 1047-1057. https://doi. org/10.3892/ijo.2011.937 
[11] SKVORTSOV S, SCHÄFER G, STASYK T, FUCHSBERGER $\mathrm{C}, \mathrm{BONN}$ GK et al. Proteomics profiling of microdissected low- and high-grade prostate tumors identifies Lamin A as a discriminatory biomarker. J Proteome Res 2011; 10: 259268. https://doi.org/10.1021/pr100921j

[12] SINGH AN, SHARMA N. Quantitative SWATH-Based Proteomic Profiling for Identification of Mechanism-Driven Diagnostic Biomarkers Conferring in the Progression of Metastatic Prostate Cancer. Front Oncol 2020; 10: 493. https://doi. org/10.3389/fonc. 2020.00493

[13] DAVALIEVA K, KIPRIJANOVSKA S, KOMINA S, PETRUSEVSKA G, ZOGRAFSKA NC et al. Proteomics analysis of urine reveals acute phase response proteins as candidate diagnostic biomarkers for prostate cancer. Proteome Sci 2015; 13: 2. https://doi.org/10.1186/s12953-014-0059-9

[14] IGLESIAS-GATO D, WIKSTRÖM P, TYANOVA S, LAVALLEE C, THYSELL E et al. The Proteome of Primary Prostate Cancer. Eur Urol 2016; 69: 942-952. https://doi. org/10.1016/j.eururo.2015.10.053

[15] KHAMIS ZI, ICZKOWSKI KA, SAHAB ZJ, SANG QX. Protein profiling of isolated leukocytes, myofibroblasts, epithelial, Basal, and endothelial cells from normal, hyperplastic, cancerous, and inflammatory human prostate tissues. J Cancer 2010; 1: 70-79. https://doi.org/10.7150/jca.1.70

[16] KWON OK, HA YS, NA AY, CHUN SY, KWON TG et al. Identification of Novel Prognosis and Prediction Markers in Advanced Prostate Cancer Tissues Based on Quantitative Proteomics. Cancer Genomics Proteomics 2020; 17: 195208. https://doi.org/10.21873/cgp.20180

[17] MCNALLY CJ, RUDDOCK MW, MOORE T, MCKENNA DJ. Biomarkers That Differentiate Benign Prostatic Hyperplasia from Prostate Cancer: A Literature Review. Cancer Manag Res 2020; 12: 5225-5241. https://doi.org/10.2147/ CMAR.S250829

[18] TIMKOVA V, TATARKOVA Z, LEHOTSKY J, RACAY P, DOBROTA D et al. Effects of mild hyperhomocysteinemia on electron transport chain complexes, oxidative stress, and protein expression in rat cardiac mitochondria. Mol Cell Biochem 2016; 411: 261-270. https://doi.org/10.1007/ s11010-015-2588-7

[19] SZKLARCZYK D, FRANCESCHINI A, WYDER S, FORSLUND K, HELLER D et al. STRING v10: Proteinprotein interaction networks, integrated over the tree of life. Nucleic Acids Res 2015; 43: D447-D452. https://doi. org/10.1093/nar/gku1003

[20] LIVAK KJ, SCHMITTGEN TD. Analysis of relative gene expression data using real-time quantitative PCR and the 2(-Delta Delta C(T)) Method. Methods 2001; 25: 402-408. https://doi.org/10.1006/meth.2001.1262

[21] WANG ET, SANDBERG R, LUO S, KHREBTUKOVA I, ZHANG L et al. Alternative isoform regulation in human tissue transcriptomes. Nature 2008; 456: 470-476. https://doi. org/10.1038/nature07509

[22] PIN E, STRATTON S, BELLUCO C, LIOTTA L, NAGLE $\mathrm{R}$ et al. A pilot study exploring the molecular architecture of the tumor microenvironment in human prostate cancer using laser capture microdissection and reverse phase protein microarray. Mol Oncol 2016; 10: 1585-1594. https://doi. org/10.1016/j.molonc.2016.09.007
[23] LIN JF, XU J, TIAN HY, GAO X, CHEN QX et al. Identification of candidate prostate cancer biomarkers in prostate needle biopsy specimens using proteomic analysis. Int J Cancer 2007; 121: 2596-2605. https://doi.org/10.1002/ ijc. 23016

[24] SEQUEIROS T, RIGAU M, CHIVA C, MONTES M, GARCIA-GRAU I et al. Targeted proteomics in urinary extracellular vesicles identifies biomarkers for diagnosis and prognosis of prostate cancer. Oncotarget 2017; 8: 4960-4976. https://doi.org/10.18632/oncotarget.13634

[25] JEDINAK A, CURATOLO A, ZURAKOWSKI D, DILLON S, BHASIN MK et al. Novel non-invasive biomarkers that distinguish between benign prostate hyperplasia and prostate cancer. BMC Cancer 2015; 15: 259. https://doi.org/10.1186/ s12885-015-1284-z

[26] UMMANNI R, MUNDT F, POSPISIL H, VENZ S, SCHARF $\mathrm{C}$ et al. Identification of clinically relevant protein targets in prostate cancer with 2D-DIGE coupled mass spectrometry and systems biology network platform. PLoS One 2011; 6: e16833. https://doi.org/10.1371/journal.pone.0016833

[27] JIANG M, SHAPPELL SB, HAYWARD SW. Approaches to understanding the importance and clinical implications of peroxisome proliferator-activated receptor gamma (PPARgamma) signaling in prostate cancer. J Cell Biochem 2004; 91: 513-527. https://doi.org/10.1002/jcb.10770

[28] BARRON DA, ROWLEY DR. The reactive stroma microenvironment and prostate cancer progression. Endocr Relat Cancer 2012; 19: R187-R204. https://doi.org/10.1530/ERC12-0085

[29] KRUŠLIN B, ULAMEC M, TOMAS D. Prostate cancer stroma: an important factor in cancer growth and progression. Bosn J Basic Med Sci 2015; 15: 1-8. https://doi.org/10.17305/ bjbms.2015.449

[30] TUXHORN JA, AYALA GE, SMITH MJ, SMITH VC, DANG TD et al. Reactive stroma in human prostate cancer: induction of myofibroblast phenotype and extracellular matrix remodeling. Clin Cancer Res 2002; 8: 2912-2923.

[31] ONG MS, DENG S, HALIM CE, CAI W, TAN TZ et al. Cytoskeletal Proteins in Cancer and Intracellular Stress: A Therapeutic Perspective. Cancers (Basel) 2020; 12: 238. https://doi. org/10.3390/cancers12010238

[32] HANAHAN D, WEINBERG RA. Hallmarks of cancer: the next generation. Cell 2011; 144: 646-674. https://doi. org/10.1016/j.cell.2011.02.013

[33] FIFE CM, McCARROLL JA, KAVALLARIS M. Movers and shakers: Cell cytoskeleton in cancer metastasis. Br J Pharmacol 2014; 171: 5507-5523. https://doi.org/10.1111/ bph. 12704

[34] BHARADWAJ S, PRASAD GL. Tropomyosin-1, a novel suppressor of cellular transformation is downregulated by promoter methylation in cancer cells. Cancer Lett 2002; 183: 205-213. https://doi.org/10.1016/s0304-3835(02)00119-2

[35] ARENTZ G, CHATAWAY T, PRICE TJ, IZWAN Z, HARDI $G$ et al. Desmin expression in colorectal cancer stroma correlates with advanced stage disease and marks angiogenic microvessels. Clin Proteomics 2011; 8: 16. https://doi. org/10.1186/1559-0275-8-16 
[36] MA Y, PENG J, LIU W, ZHANG P, HUANG L et al. Proteomics identification of desmin as a potential oncofetal diagnostic and prognostic biomarker in colorectal cancer. Mol Cell Proteomics 2009; 8: 1878-1890. https://doi.org/10.1074/ mcp.M800541-MCP200

[37] LI Q, LI Y, WANG Y, CUI Z, GONG L et al. Quantitative proteomic study of human prostate cancer cells with different metastatic potentials. Int J Oncol 2016; 48: 1437-1446. https://doi.org/10.3892/ijo.2016.3378

[38] GEISLER C, GAISA NT, PFISTER D, FUESSEL S, KRISTIANSEN $G$ et al. Identification and validation of potential new biomarkers for prostate cancer diagnosis and prognosis using 2D-DIGE and MS. Biomed Res Int 2015; 2015: 454256. https://doi.org/10.1155/2015/454256

[39] WU JP, HUANG WB, ZHOU H, XU LW, ZHAO JH et al. Intensity of stromal changes is associated with tumor relapse in clinically advanced prostate cancer after castration therapy. Asian J Androl 2014; 16: 710-714. https://doi. org/10.4103/1008-682X.129131

[40] AYALA G, TUXHORN JA, WHEELER TM, FROLOV A, SCARDINO PT et al. Reactive stroma as a predictor of biochemical-free recurrence in prostate cancer. Clin Cancer Res 2003; 9: 4792-4801.

[41] STROUHALOVA D, MACEJOVA D, MOSNA B, BOBAL P, OTEVREL J et al. Down-regulation of vimentin by triorganotin isothiocyanates-nuclear retinoid $\mathrm{X}$ receptor agonists: $\mathrm{A}$ proteomic approach. Toxicol Lett 2020; 318: 22-29. https:// doi.org/10.1016/j.toxlet.2019.10.004

[42] ZHAO Y, YAN Q, LONG X, CHEN X, WANG Y. Vimentin affects the mobility and invasiveness of prostate cancer cells. Cell Biochem Funct 2008; 26: 571-577. https://doi. org/10.1002/cbf.1478

[43] KAWAHARA R, RECUERO S, NOGUEIRA FCS, DOMONT GB, LEITE KRM et al. Tissue Proteome Signatures Associated with Five Grades of Prostate Cancer and Benign Prostatic Hyperplasia. Proteomics 2019; 19: e1900174. https://doi. org/10.1002/pmic.201900174

[44] WU M, BAI X, XU G, WEI J, ZHU T et al. Proteome analysis of human androgen-independent prostate cancer cell lines: variable metastatic potentials correlated with vimentin expression. Proteomics 2007; 7: 1973-1983. https://doi. org/10.1002/pmic.200600643

[45] LEXANDER H, FRANZÉN B, HIRSCHBERG D, BECKER S, HELLSTRÖM $M$ et al. Differential protein expression in anatomical zones of the prostate. Proteomics 2005; 5: 25702576. https://doi.org/10.1002/pmic.200401170

[46] WEI J, XU G, WU M, ZHANG Y, LI Q et al. Overexpression of vimentin contributes to prostate cancer invasion and metastasis via src regulation. Anticancer Res 2008; 28: 327-334.

[47] YAN CQ, LU YH, TANG SM, FAN WX. MiR-519d inhibits prostate cancer cell proliferation, cycle and invasion via targeting NRBP1. Eur Rev Med Pharmacol Sci 2018; 22: 29852990. https://doi.org/10.26355/eurrev_201805_15054

[48] BHAGIRATH D, YANG TL, BUCAY N, SEKHON K, MAJID S et al. microRNA-1246 Is an Exosomal Biomarker for Aggressive Prostate Cancer. Cancer Res 2018; 78: 1833-1844. https://doi.org/10.1158/0008-5472.CAN-17-2069
[49] FENG YG, ZHAO JF, XIAO L, RAO WY, RAN C et al. MicroRNA-19a-3p suppresses invasion and metastasis of prostate cancer via inhibiting SOX4. Eur Rev Med Pharmacol Sci 2018; 22: 6245-6251. https://doi.org/10.26355/eurrev_201810_16031

[50] JIANG Z, ZHANG Y, CHEN X, WU P, CHEN D. Inactivation of the Wnt $/ \beta$-catenin signaling pathway underlies inhibitory role of microRNA-129-5p in epithelial-mesenchymal transition and angiogenesis of prostate cancer by targeting ZIC2. Cancer Cell Int 2019; 19: 271. https://doi.org/10.1186/ s12935-019-0977-9

[51] WILLIAMS LV, VELICEASA D, VINOKOUR E, VOLPERT OV. miR-200b inhibits prostate cancer EMT, growth and metastasis. PLoS One 2013; 8: e83991. https://doi.org/10.1371/ journal.pone.0083991

[52] KRISHNAMACHARY B, BERG-DIXON S, KELLY B, AGANI F, FELDSER D et al. Regulation of colon carcinoma cell invasion by hypoxia-inducible factor 1 . Cancer Res 2003; 63: 1138-1143.

[53] SHI AM, TAO ZQ, LI R, WANG YQ, WANG X, et al. Vimentin and post-translational modifications in cell motility during cancer - a review. Eur Rev Med Pharmacol Sci 2016; 20: 2603-2606.

[54] NAKAMURA F, STOSSEL TP. The filamins: organizers of cell structure and function. Cell Adhes Migr 2011; 5: 160169. https://doi.org/10.4161/cam.5.2.14401

[55] SHAO QQ, ZHANG TP, ZHAO WJ, LIU ZW, YOU L, et al. Filamin A: Insights into its Exact Role in Cancers. Pathol Oncol Res 2016; 22: 245-252. https://doi.org/10.1007/ s12253-015-9980-1

[56] BEDOLLA RG, WANG Y, ASUNCION A, CHAMIE K, SIDDIQUI $S$ et al. Nuclear versus cytoplasmic localization of filamin A in prostate cancer: immunohistochemical correlation with metastases. Clin Cancer Res 2009; 15: 788-796. https://doi.org/10.1158/1078-0432.CCR-08-1402

[57] SUN GG, LU YF, ZHANG J, HU WN. Filamin A regulates MMP-9 expression and suppresses prostate cancer cell migration and invasion. Tumour Biol 2014; 35: 3819-3826. https://doi.org/10.1007/s13277-013-1504-6

[58] SAVOY RM, GHOSH PM. The dual role of filamin A in cancer: can't live with (too much of) it, can't live without it. Endocr Relat Cancer 2013; 20: R341-356. https://doi. org/10.1530/ERC-13-0364

[59] CALDERWOOD SK, KHALEQUE MA, SAWYER DB, CIOCCA DR. Heat shock proteins in cancer: chaperones of tumorigenesis. Trends Biochem Sci 2006; 31: 164-172. https:// doi.org/10.1016/j.tibs.2006.01.006

[60] SAMALI A, ROBERTSON JD, PETERSON E, MANERO F, VAN ZEIJL L et al. Hsp27 protects mitochondria of thermotolerant cells against apoptotic stimuli. Cell Stress Chaperones 2001; 6: 49-58. https://doi.org/10.1379/14661268(2001)006<0049:hpmotc >2.0.co;2

[61] CHO SY, KANG S, KIM DS, NA HJ, KIM YJ et al. A HSP27, ALDH6A1 and Prohibitin Act as a Trio-biomarker to Predict Survival in Late Metastatic Prostate Cancer. Anticancer Res 2018; 38: 6551-6560. https://doi.org/10.21873/anticanres. 13021 
[62] FOSTER CS, DODSON AR, AMBROISINE L, FISHER G, MØLLER $\mathrm{H}$ et al. Hsp-27 expression at diagnosis predicts poor clinical outcome in prostate cancer independent of ETS-gene rearrangement. Br J Cancer 2009; 101: 1137-1144. https://doi.org/10.1038/sj.bjc.6605227

[63] ROCCHI P, BERALDI E, ETTINGER S, FAZLI L, VESSELLA RL et al. Increased Hsp27 after androgen ablation facilitates androgen-independent progression in prostate cancer via signal transducers and activators of transcription 3-mediated suppression of apoptosis. Cancer research 2005; 65: 11083-11093. https://doi.org/10.1158/0008-5472.CAN05-1840

[64] HOTER A, NAIM HY. Heat Shock Proteins and Ovarian Cancer: Important Roles and Therapeutic Opportunities. Cancers (Basel) 2019; 11: 1389. https://doi.org/10.3390/cancers11091389

[65] NAHOMI RB, PALMER A, GREEN KM, FORT PE, NAGARAJ RH. Pro-inflammatory cytokines downregulate Hsp27 and cause apoptosis of human retinal capillary endothelial cells. Biochim Biophys Acta 2014; 1842: 164-174. https://doi. org/10.1016/j.bbadis.2013.11.011

[66] SCHÄFER C, SEELIGER H, BADER DC, ASSMANN G, BUCHNER D et al. Heat shock protein 27 as a prognostic and predictive biomarker in pancreatic ductal adenocarcinoma. J Cell Mol Med 2012; 16: 1776-1791. https://doi. org/10.1111/j.1582-4934.2011.01473.x
[67] HAN M, DONG LH, ZHENG B, SHI JH, WEN JK et al. Smooth muscle 22 alpha maintains the differentiated phenotype of vascular smooth muscle cells by inducing filamentous actin bundling. Life Sci 2009; 84: 394-401. https://doi. org/10.1016/j.lfs.2008.11.017

[68] DVORAKOVA M, LAPCIK P, BOUCHALOVA P, BOUCHAL P. Transgelin Silencing Induces Different Processes in Different Breast Cancer Cell Lines. Proteomics 2020; 20: e1900383. https://doi.org/10.1002/pmic.201900383

[69] ZHANG ZW, YANG ZM, ZHENG YC, CHEN ZD. Transgelin induces apoptosis of human prostate LNCaP cells through its interaction with p53. Asian J Andrology 2010; 12: 186-195. https://doi.org/10.1038/aja.2009.76

[70] WEBBER JP, SPARY LK, MASON MD, TABI Z, BREWIS IA et al. Prostate stromal cell proteomics analysis discriminates normal from tumour reactive stromal phenotypes. Oncotarget 2016; 7: 20124-20139. https://doi.org/10.18632/oncotarget.7716

[71] KOYAMA M, MATSUURA Y. Crystal structure of importin- $\alpha 3$ bound to the nuclear localization signal of Ranbinding protein 3. Biochem Biophys Res Commun 2017; 491: 609-613. https://doi.org/10.1016/j.bbrc.2018.03.006 